\title{
STUDIES IN PROTEIN INTOXICATION
}

\author{
I. BLOOD COAGULATION * \\ HOWARD F. SHATTUCK, M.D. \\ NEW YORK
}

Since the first report on the use of human serum in certain diseases of the skin six years ago, ${ }^{1}$ varying reports of its value for these conditions have appeared, many of them favorable. The work here reported is a continuation of that started by Swann, ${ }^{2}$ and is concerned with further studies on the use of human serum in urticaria, especially regarding the effect of such serum on the coagulation factors of the blood in this condition.

Urticaria is believed by many to be an anaphylactic manifestation. Swann's ${ }^{2}$ observation of the delayed coagulation of the blood in the case of urticaria he studied harmonizes with the conception of urticaria as a clinical manifestation of anaphylaxis, as in the latter condition the coagulation time of the whole blood is definitely delayed. Strickler ${ }^{3}$ found that eight out of ten cases of urticaria showed positive anaphylactic skin reactions, even though the results of these tests did not, as a rule, lead to therapeutic success. McBride and Schorer ${ }^{4}$ have pointed out the definite position of anaphylaxis as a cause of urticaria, assigning most cases to that cause.

Widal ${ }^{5}$ and his co-workers observed in their study of chronic urticaria that the ingestion of animal proteins to which the individual was sensitized, induced a series of disturbances definitely anaphylactic in character, namely, a fall in blood pressure, leukopenia, hypercoagulability (?) of the blood, profound lowering of the refractometric index, a rise of temperature and albuminuria. He concluded that these findings are caused by the passage of heterogeneous albumins into the blood.

The beneficial results obtained in some cases of urticaria from protein restriction in accordance with positive anaphylactic skin reactions, also lend weight to this view, as does the urticaria observed in indi-

* Submitted for publication April 12, 1917.

* From the Department of Pathology and the Medical Clinic, Presbyterian Hospital, Columbia University.

1. Mayer and Linser: München. med. Wchnschr., 1910, 56, 2757. Linser, P.: Med. Klin., 1911, 7, 1361 ; Verhandl. d. Cong. f. inn. med., 1911, 28, 125, and Arch. f. Dermat. u. Syph., 1912, 113, 701.

2. Swann, Arthur W.: Jour. Am. Med. Assn., 1915, 64, 737.

3. Strickler, Albert: New York Med. Jour., 1916, 104, 198.

4. McBride and Schorer: Jour. Cutan. Dis., 1916, 34, 70.

5. Widal, F.: Bull. et mém. Soc. méd. d. hôp. de Paris, 1914, 37, 256. 
viduals after the ingestion of certain food. The almost constant appearance of general urticaria in such a definite anaphylactic conditions as serum disease is also most suggestive.

These considerations led me to precede my study of the coagulation factors in urticaria and the influence on these factors of human serum therapy, with a study of the blood in experimental anaphylactic guineapigs and in cases of serum sickness in man.

Biedl and Kraus ${ }^{6}$ first observed the delay or loss of coagulability of the blood of dogs suffering from anaphylactic shock. The delay amounted to hours or days. Friedberger ${ }^{7}$ found that the coagulability of the guinea-pig's blood is lessened in anaphylaxis, but the diminution was slight as compared to that described by Biedl and Kraus ${ }^{6}$ in the dog, the delay being only a matter of minutes. Since then, other workers have observed the same condition, in this country, Pepper and Krumbhaar, ${ }^{8}$ Lee and Vincent, ${ }^{9}$ and recently Minot. ${ }^{10}$ Many have the impression that the delayed coagulability of the blood in anaphylactic animals is a matter of hours or days and of uniform occurrence in all anaphylactic animals. That this is not the case was shown first by Friedberger. $^{7}$ Pepper and Krumbhaar's ${ }^{8}$ report of their work with dogs, in which the delay is most marked, shows that in only four out of seven cases reported did the delay amount to hours instead of minutes. Lee and Vincent ${ }^{9}$ give no figures. Minot's ${ }^{10}$ results were essentially the same. My work was confined to guinea-pigs.

The following was the technic used: Guinea-pigs were given a sensitizing intravenous injection of 0.5 c.c. of horse serum. Twenty-one days later a second 0.5 c.c. of horse serum was given and if anaphylactic shock developed, as shown by convulsions, dyspnea, weakness, involuntary defecation and urination, etc., blood was drawn from the heart and one portion put at once into sodium oxylate solution and later tested for the amount or efficiency of prothrombin, Howell's ${ }^{13}$ method as described by Minot ${ }^{12}$ being employed. Antithrombin was tested by the method described by Hess. ${ }^{13}$ A second portion was used to test the coagulation of the whole blood by the method described by Lee and White. ${ }^{14}$ Every effort was made to carry out the methods just mentioned, as exactly described by the various authors, with the utmost care as to the details of the technic.

As the blood of only one anaphylactic guinea-pig was tested on any one day, a normal nonanaphylactic guinea-pig's blood was used as a control in each case. The results of these studies appear in Table 1.

6. Biedl and Kraus: Wien. klin. Wchnschr., 1909, 20, 763.

7. Friedberger, E.: Ztschr. f. Immunitätsforsch., 1909-1910, Orig. 4, 636.

8. Pepper and Krumbhaar: Jour. Infect. Dis., 1914, 14, 476.

9. Lee and Vincent: Jour. Med. Research, 1915, 27, 445.

10. Minot, G. R.: Personal communication.

11. Howell, W. H.: The Archives Int. Med., 1914, 13, 76.

12. Minot, Denny and Davis: The Archives Int. Med., 1916, 17, 101.

13. Hess, Alfred F.: Jour. Exper. Med., 1915, 21, 338.

14. Lee and White: Am. Jour. Med. Sc., 1913, 145, 495. 
TABLE 1.-Effect of Horse Serum Injections on Blood of Normal and Anaphylactic Guinea-Pigs

\begin{tabular}{|c|c|c|c|c|c|c|c|c|c|c|c|c|}
\hline \multirow{3}{*}{ Exper. } & \multirow{3}{*}{ Date } & \multirow{3}{*}{$\begin{array}{c}\text { Experimental } \\
\text { Animal }\end{array}$} & \multirow{2}{*}{\multicolumn{2}{|c|}{$\begin{array}{c}\text { Coagu- } \\
\text { lation } \\
\text { Time } \\
\text { of Whole } \\
\text { Blood }\end{array}$}} & \multirow{2}{*}{\multicolumn{2}{|c|}{$\begin{array}{l}\text { Prothrom: } \\
\text { bin }\end{array}$}} & \multicolumn{6}{|c|}{ Antithrombin (Hess Method) } \\
\hline & & & & & & & \multicolumn{2}{|c|}{ Control } & \multicolumn{2}{|c|}{$\begin{array}{l}3 \text { Drops } \\
\text { Anti- } \\
\text { thrombin }\end{array}$} & \multicolumn{2}{|c|}{$\begin{array}{c}5 \text { Drops } \\
\text { Anti- } \\
\text { thrombin }\end{array}$} \\
\hline & & & Min. & Sec. & Min. & Sec. & Min. & Sec. & Min. & Sec. & Min. & Sec. \\
\hline \multirow[t]{2}{*}{1} & \multirow[t]{2}{*}{$3 / 3 / 16$} & \multirow{2}{*}{$\begin{array}{c}\text { Control } \\
\text { Anaphylactic } \\
\text { guinea-pig }\end{array}$} & 2 & 30 & 3 & .. & 2 & 45 & 3 & .. & 3 & .. \\
\hline & & & 6 & .. & 9 & .. & .. & .. & 8 & 30 & 9 & .. \\
\hline \multirow[t]{2}{*}{2} & \multirow[t]{2}{*}{$3 / 13 / 16$} & \multirow{2}{*}{$\begin{array}{c}\text { Control } \\
\text { Anaphylactic } \\
\text { guinea-pig }\end{array}$} & 4 & .. & 3 & 30 & 3 & .. & 2 & .. & 3 & .. \\
\hline & & & 16 & 30 & 14 & .. & .. & .. & 6 & .. & 6 & 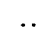 \\
\hline \multirow[t]{2}{*}{3} & \multirow[t]{2}{*}{$3 / 15 / 16$} & \multirow{2}{*}{$\begin{array}{c}\text { Control } \\
\text { Anaphylactje } \\
\text { guinea-pig }\end{array}$} & 1 & 30 & 3 & 20 & 2 & .. & 3 & .. & 7 & 30 \\
\hline & & & 21 & · & 19 & 30 & .. & .. & $\theta$ & 30 & 15 & .. \\
\hline \multirow[t]{2}{*}{4} & \multirow[t]{2}{*}{$3 / 24 / 16$} & \multirow{2}{*}{$\begin{array}{c}\text { Control } \\
\text { Anaphylactie } \\
\text { guinea-pig }\end{array}$} & 5 & 30 & 4 & $\cdots$ & 3 & 30 & 3 & $\cdots$ & 4 & 30 \\
\hline & & & 12 & .. & 14 & 30 & .. & .. & 3 & 30 & 3 & 30 \\
\hline \multirow[t]{2}{*}{5} & \multirow[t]{2}{*}{$3 / 26 / 16$} & \multirow{2}{*}{$\begin{array}{c}\text { Coutrol } \\
\text { Anaphylactic } \\
\text { guinea-pig }\end{array}$} & 2 & .. & 3 & 80 & 2 & 30 & 4 &.. & 4 & .. \\
\hline & & & 9 & 30 & 8 & .. & .. & .. & 7 & .. & 9 & 30 \\
\hline \multirow[t]{2}{*}{ 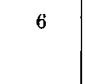 } & \multirow[t]{2}{*}{$4 / 3 / 16$} & \multirow{2}{*}{$\begin{array}{c}\text { Contiol } \\
\text { Anaphylactic } \\
\text { guinea-pig }\end{array}$} & 2 & .. & 3 & 30 & 3 & .. & 3 & .. & 2 & 30 \\
\hline & & & 39 & 30 & 24 & 30 & .. &.. & 7 & .. & 9 & 30 \\
\hline
\end{tabular}

A study of Table 1 shows that the coagulation time of the whole blood and the prothrombin time were uniformly delayed in the anaphylactic guinea-pigs. The determinations for antithrombin content were rather unsatisfactory and inconstant, as will be seen from the table, but there seemed to be a tendency to higher figures in the case of the anaphylactic blood. The unsatisfactory results may possibly be due to the fact that the Hess method is unsuitable for cases showing only slight variation in antithrombin content. Minot's ${ }^{10}$ results in similar studies were essentially the same, though in some instances he succeeded in obtaining anaphylactic guinea-pig's blood that did not clot for hours; in one instance only after twenty-four.

Various findings accompanying the delayed coagulability of the blood in anaphylactic animals have been reported as possibly expraining the phenomenon. Sirensky, ${ }^{15}$ in his work, reports that the fibrinogen and fibrin ferment were slightly decreased, while the calcium and magnesium content was unchanged. Conflicting reports occur as to the platelets. Achard and Aynaud ${ }^{16}$ found an associated disappearance of platelets, while Biedl and Kraus ${ }^{6}$ found the contrary. Some observers report a deficiency in the calcium content of the blood, but Pepper and Krumbhaar $^{8}$ report opposite findings. The latter attribute the delay in

15. Sirensky. Ztschr. f. Immunitätsforsch., 1910, 5, 516.

16. Achard and Aynaud: Compt. rend. Soc. de biol., 1909, 67, 83. 
coagulation to an abnormally small amount of thromboplastin, or to an excess of antithrombin. In support of the former theory they point out that the addition of calcium and thromboplastin solution constantly produced a more rapid coagulation than any other method. Somewhat suggestive of the latter view, though rather unsatisfactorily so, are the author's and Minot's findings of a tendency to high antithrombin figures in anaphylactic animal blood.

Studies were also made in the coagulation factors of the blood in known anaphylactic conditions in man, namely, in cases of serum sickness. Von Witzinger ${ }^{\mathbf{1 7}}$ found in studying the effect of foreign serum injections in man on the coagulation of the blood, that the first injection was regularly followed by an acceleration of the coagulation, which subsided in twenty-four hours; also, that a second acceleration followed on the seventh, eighth, or tenth day after the injection, lasting a little longer than the first period. The reinjection of serum, however, was followed in five or six hours by a marked retardation of coagulation. This was most marked, he found, in cases in which the blood drawn directly from the vein was examined. His method of coagulation, however, can scarcely be said to be as accurate as those recently described, in view of the recent studies and theories of blood coagulation.

The author studied the coagulation time of the whole blood, the prothrombin time and antithrombin content in two cases of serum sickness following the injection of antipneumococcus serum in cases of lobar pneumonia, on the medical service of Dr. Longcope at the Presbyterian Hospital.

\section{REPORT CF CASES}

CASE 1.-C. M., aged 38, merchant, was admitted March 18, 1916; discharged April 24, 1916. The diagnosis was lobar pneumonia. There was a history of cough and fever for four days before admission. Examination showed physical signs of consolidation of lower lobe of the left lung. Blood culture and sputum both showed pneumococcus, Group I. The patient received 80 c.c. antipneumococcus serum, Group I, with 80 c.c. sterile saline twice, March 19, 1916, and two similar doses of serum and saline, March 20, 1916. Serum sickness developed, beginning March 27, 1916, with extensive general urticaria, erythema, enlarged lymph nodes, swelling and puffiness of face and eyes, and joint pains. With his blood later passive anaphylaxis was transferred to guinea-pigs and his skin reacted positively to horse serum. March 24, 1916, coagulation time of the whole blood (Lee and White method) was 11 minutes; control, 9 minutes; prothrombin time, 10 minutes; control, 9 minutes. April 8, 1916 (10 days after onset of serum sickness), the coagulation time of the whole blood was 24 minutes; control, 7 minutes; prothrombin time, 21 minutes; control, $81 / 2$ minutes. May 29, 1916, the coagulation time of the whole blood was 14 minutes; control, 8 minutes; prothrombin time, $12 \frac{1}{2}$ minutes; control, $71 / 2$ minutes.

CASE 2.-W. B., aged 38, was admitted Feb. 4, 1916; discharged March 10, 1916. Diagnosis, lobar pneumonia. There was a history of pain in the left side, with cough and fever for four days before admission. Examination showed

17. Von Witzinger, Oscar: Ztschr. f. Kinderh., 1911-1912, 3, 211. 
physical signs of consolidation of the left lower lobe. Blood culture was sterile. The sputum showed pneumococcus, Group I. The patient received 80 c.c. of antipneumococcus serum, Group I, with 80 c.c. sterile saline intravenously. Feb. 13, 1916, serum sickness developed; enlarged lymph nodes, joint pains, temperature, puffy face, diminished urine output and urticaria. Feb. 10, 1916, coagulation time of whole blood, 9 minutes; control, $9 \frac{1}{2}$ minutes; prothrombin time, 10 minutes; control 9 minutes. Feb. 16, 1916 (four days after development of serum sickness), coagulation time of whole blood, $181 / 2$ minutes; control, $6^{1 / 2}$ minutes; prothrombin time, 20 minutes; control, $9 \frac{1 / 2}{2}$ minutes. The patient was not obtained for further examination.

The tabulated results of these two cases tppear in Table 2.

Turning now to the study of the coagulation factors in urticaria, the author studied the coagulation time of the whole blood, the prothrombin and antithrombin content, before and after treatment with

TaBle 2.-Results of Blood Examination in Cases 1 and 2 After AntipNeumococcus Serum, Group I

\begin{tabular}{|c|c|c|c|c|c|c|c|c|c|c|c|c|}
\hline \multirow{3}{*}{ Case } & \multirow{3}{*}{ Date } & \multirow{3}{*}{$\begin{array}{c}\text { Time of } \\
\text { Examination }\end{array}$} & \multirow{2}{*}{\multicolumn{2}{|c|}{$\begin{array}{l}\text { Coagu- } \\
\text { lation } \\
\text { Time } \\
\text { of Whole } \\
\text { Blood }\end{array}$}} & \multirow{2}{*}{\multicolumn{2}{|c|}{$\begin{array}{c}\text { Prothrom } \\
\text { bin }\end{array}$}} & \multicolumn{6}{|c|}{ Antithrombin (Hess Method) } \\
\hline & & & & & & & \multicolumn{2}{|c|}{ Control } & \multicolumn{2}{|c|}{$\begin{array}{l}3 \text { Drops } \\
\text { Anti- } \\
\text { thrombin }\end{array}$} & \multicolumn{2}{|c|}{$\begin{array}{l}5 \text { Drops } \\
\text { Anti- } \\
\text { thrombin }\end{array}$} \\
\hline & & & Min. & Sec. & Min. & See. & Min. & Sec. & Min. & Sec. & Min. & Sec. \\
\hline \multirow[t]{6}{*}{ 1. O. $\mathbf{M}$. } & \multirow[t]{2}{*}{$3 / 24 / 16$} & \multirow{2}{*}{$\begin{array}{c}3 \text { days before } \\
\text { serum sickness } \\
\text { Control }\end{array}$} & 11 & .. & 10 & .. & 9 & 30 & 10 & .. & 10 & .. \\
\hline & & & 9 & . & 9 & . & $\cdots$ & $\cdots$ & 9 & 30 & 11 & .. \\
\hline & \multirow[t]{2}{*}{ 4/ $8 / 16$} & \multirow{2}{*}{$\begin{array}{l}\text { During serum } \\
\text { sickness } \\
\text { Control }\end{array}$} & 24 & .. & 21 & .. & 8 & 30 & 10 & 30 & 10 & 30 \\
\hline & & & 7 & .. & 8 & 30 & .. & .. & 10 & .. & 11 & 30 \\
\hline & \multirow[t]{2}{*}{$5 / 29 / 16$} & \multirow{2}{*}{$\begin{array}{l}\text { After serum } \\
\text { sickness } \\
\text { Control }\end{array}$} & 14 & .. & 12 & 30 & 8 & .. & 8 & .. & 9 & 30 \\
\hline & & & 8 & .. & 7 & 30 & . & .. & 8 & 30 & 8 & 30 \\
\hline \multirow[t]{4}{*}{ 2. W. B. } & \multirow[t]{2}{*}{$2 / 10 / 16$} & $\begin{array}{l}3 \text { days before } \\
\text { serum sickness }\end{array}$ & 9 & *. & 10 & .. & 10 & .. & 9 & . & 9 & 30 \\
\hline & & Control & 9 & 30 & 9 & .. & .. & .. & 8 & 30 & 11 & .. \\
\hline & \multirow[t]{2}{*}{$2 / 16 / 16$} & During serum & 18 & 30 & 20 & .. & 9 & .. & 13 & 30 & 12 & 30 \\
\hline & & & 6 & 30 & 9 & 30 & .. & . & 10 & 30 & 10 & . \\
\hline
\end{tabular}

autogenous or heterogenous serum. Widal ${ }^{5}$ and his co-workers report a condition of hypercoagulability of the blood in a case of chronic urticaria after the ingestion of animal proteins. Wright and Paramore, ${ }^{18}$ however, report delayed coagulability of the blood in cases of urticaria, due, they believed, to a deficiency in calcium content. Nixon ${ }^{19}$ found the blood coagulation time delayed in his cases of urticaria tuberosa of Willan, a condition closely related to ordinary urticaria. Minot, ${ }^{10}$ in a study of three cases of severe urticaria, found the coagulation time of

18. Wright and Paramore: Lancet, London, 1905, 2, 1096.

19. Nixon, J. A.: Quart. Jour. Med., 1916, 9. 245. 
the blood and the prothrombin time normal in two cases and delayed in one. The antithrombin factor he found to be normal. The histories of the cases studied by the author follow, and later is found a table of the results obtained in the coagulation factors of the blood both before and after the treatment with autogenous or heterogenous serum.

CASE 3.--L. M. S., nurse, aged 30, was seen first May 15, 1916, complaining of severe attacks of hives for six months. The family history was negative and revealed no asthma, urticaria or hay-fever. The patient's appetite was good; she took two cups of coffee and one of tea a day. She had been constipated for four years. She worked hard and was frequently under a great deal of nervous strain. Menstruation was normal. She had had typhoid fever and an operation for appendicitis; otherwise, she had always been well; no hay-fever or asthma. Three years previously she had had a slight attack of hives of unknown cause. Prior to her present attack she ate anything and everything and it alweys agreed with her. In December, 1915, while nursing at the American Hospital in France, the patient developed a severe attack of hives, with itching and burning, involving the arms, ankles, abdomen and chest. The patient said it followed the eating of some queer meat, either horse or cat, and that some of the other nurses had hives as well. The patient used sodium bicarbonate and calcium lactate without relief. She returned to the United States in January, 1916. The hives continued in very severe form until May 15, when first seen. Many remedies were tried, but nothing but epinephrin subcutaneously gave relief, and that only temporarily. The patient weighed 121 pounds. She was rather nervous. Physical examination showed a dry, rough skin, without petechiae, but with several urticarial spots on the arms and shoulders. There was a moderate dermographia. The color was good. Eyes, throat and teeth were normal. There were a few lymph nodes the size of peas in each posterior cervical chain. The lungs were clear and heart normal. Abdomen and extremities were negative. The blood pressure was 118-76. The blood showed: red blood cells, 4,800,000; hemoglobin, 85 per cent.; leukocytes, 9,600; polymorphs, 68 per cent.; lymphocytes, 32 per cent.; no eosinophils. The stool was soft, pasty, semiformed. Whole peas, cucumber seeds and spinach were easily recognized; no mucus, pus, or blood. Urobilin, slight; carbohydrate fermentation, slight; trypsin and amylopsin, normal. Microscopically: starch particles, much cellulose; no increase in the total fat; no mucus, pus, or blood; no ova or parasites; many muscle fibers, with round corners and few striations; gramnegative organisms about 60 per cent. of the total number. Skin tests, intradermic method, were carried out by Dr. Frank Rackermann. Horse, sheep, dog, milk, beef, egg, cat, pig, rabbit, ragweed and goldenrod all gave negative results. The patient's serum, tested with horse and rabbit serum in various dilutions, gave no evidence of precipitins. Guinea-pig blood, sensitive to rabbit and horse serum, treated with patient's serum gave no precipitins. Coagulation time of whole blood (Lee and White method), twenty minutes; control, eight minutes; prothrombin time, seventeen minutes; control, nine minutes. For antithrombin contents and complete blood findings, see Table 3. The patient was put on an anticonstipation diet, excluding meat, milk, fish, eggs and raw fruit; calcium lactate and epinephrin hypodermatically as needed for severe attacks. At first she improved rapidly on this régime, but she relapsed in a few days and had several severe attacks of hives, involving usually the arms, legs, back and face. One of the attacks she thought was caused by eggs and another by lobster.

As the condition was improving very little, it was decided to treat the patient with serum intravenously. Accordingly, she was given varying amounts of serum obtained from two members of the house staff of the Presbyterian Hospital after the customary tests for Wassermann reaction, hemolysis, agglutination, etc., had been made. The patient belonged to Group II. 
May 25, 15 c.c. serum were given intravenously. There was no reaction. The patient had slight headache. There were a few hives on the ankle that evening.

June 4, the patient had been having some hives off and on since May 25, relieved by epinephrin. She was still constipated. She was given 20 c.c. serum intravenously. There was no reaction. She was put on a diet that excluded meats, but not chicken, fish, eggs, milk, cheese and fruits, and was given a proprietary laxative twice a day. Coagulation time of the whole blood, 14 minutes; control, 9 minutes; prothrombin time, 17 minutes; control, 11 minutes.

June 14, hives less; only a few at a time and itched less; given 15 c.c. serum intravenously; no reaction. Eggs were added to the diet by request.

June 22, had had several severe attacks of hives, most severe since beginning treatment. Eggs and chicken were stopped again; given 18 c.c. serum intravenously. No reaction.

June 25, very few hives. "Feels much better generally." Fourteen c.c. serum given intravenously.

June 29 , no hives since June $24 ; 15$ c.c. serum given intravenously, (Sixth and last dose.)

September 12, the patient returned from a vacation in the Adirondacks. She reported that she had an occasional attack of hives-only two or three at a time-until July 4, and after that none at all. "No real hives since June 18." After the beginning of July the patient felt perfectly well; her nerves were much better and the constipation was relieved; she ate anything and everything with impunity. Coagulation time of the whole blood, 10 minutes; control, 8 minutes; prothrombin time, 9 minutes; control, $91 / 2$ minutes.

CASE 4.-J. S., aged 25, valet, was admitted to the Presbyterian Hospital March 1, 1916, complaining of headache and fever. Negative family history; no urticaria, eczema, asthma or hay-fever; had diphtheria at 6 and Neisser infection seven years prior to admission; otherwise he had been well. In January, 1916, the patient ate lobster salad while in Nassau-off-Florida, and during the following twenty-four hours had severe abdominal cramps, diarrhea and vomiting; also extensive eruption of hives involving face, abdomen, back and legs, and accompanied by unbearable itching. The gastro-intestinal symptoms subsided after twenty-four hours, but the hives continued off and on until admission. On admission he had a severe headache, felt weak and prostrated, and had had a severe eruption of hives for twenty-four hours. His temperature was $102 \mathrm{~F}$., pulse 88 , respirations 18 . His appearance was that of the early stage of typhoid fever. The physical examination was negative, except for moderate enlargement of the inguinal and posterior cervical lymph nodes on both sides. Blood pressure, 124-80; weight, 108 pounds; blood culture was sterile; von Pirquet, negative; blood count showed leukocytes, on admission, 13,000 , with 80 per cent. polynuclears, 20 per cent. 1ymphocytes; no eosinophils. Three days later when the temperature came down to normal the leukocytes were 5,200 , with 54 per cent. polynuclears and 46 per cent. lymphocytes; no eosinophils. Lumbar puncture yielded negatives results. During his stay in the hospital the patient continued to have an extensive urticarial eruption, with occasional joint pains. He left the hospital after three days fully recovered except for the urticaria, which continued.

March 18, after leaving the hospital the patient was quite well except that the urticaria persisted. Coagulation time of the whole blood (Lee and White method), 14 minutes; control, 10 minutes; prothrombin time, 11 minutes; control, $11 \frac{1}{2}$ minutes.

April 5, had had joint pains from time to time and urticaria had been most severe of late, interfering with his sleep during the previous four nights. $\mathrm{He}$ was put on a strictly vegetarian diet; no meat, eggs, milk, cheese or fish. Serum treatment was started. Between April 14 and June 20 the patient received six doses of autogenous serum; the amount of each dose was from 12 c.c. to 20 c.c. 
No reaction occurred. Autogenous serum was used because of difficulty in securing a regular donor, and because it seemed desirable to see if autogenous serum had the same effect as serum from other persons. During this time the patient had some joint pain and a varying amount of urticaria, until after the third dose of serum, May 25. After that he had no hives, and only occasional joint pain, until June 1; after that none. The patient was last seen Oct. 14, 1916. He had been perfectly well since June 1 ; no urticaria and no joint pains. Coagulation time of whole blood, $91 / 2$ minutes; control, 7 minutes; prothrombin time, 10 minutes; control, $10 \frac{1}{2}$ minutes. See Table 3.

CASE 5.-K. H., aged 17, woman, clerk, was first seen at the Presbyterian Dispensary, Sept. 16, 1915, complaining of indigestion and skin trouble lasting for six months. Negative family history; no urticaria, eczema, asthma, or hayfever. She had had measles, diphtheria in 1914, and had received two doses of antitoxin. She says she had difficulty in breathing after antitoxin. She slept well and had a good appetite. Menstruation was normal and easy. Six months previously the patient began to have urticaria, with intense itching and dermographia. The urticaria was general and constant when first seen, worse she thought, after eating eggs or meat. She was troubled considerably with stomach gas. The bowels were regular and urination normal. She was well developed and had a good color. The tongue was coated. Throat, heart, lungs and abdomen were negative. There was extensive urticarial eruption over the back, legs, abdomen and neck. The eyes and lips were not involved. She was put on a diet excluding meat and eggs, without benefit.

September 21, intradermic skin tests for sensitization were made by $\mathrm{Dr}$. Rackermann. She gave a slight, though definite, reaction to horse serum; others were negative.

January 18 , the urticaria had improved at times, then returned as severely as before. She had become discouraged about dieting and now ate what she pleased. Calcium lactate had no effect. She was relieved temporarily by epinephrin. The blood pressure was 110-76; red blood corpuscles, 4,600,000; hemoglobin, 88 per cent.; leukocytes, 9,600; polymorphs, 70 per cent.; lymphocytes, 28 per cent.; eosinophils, 2 per cent., and the coagulation time of the whole blood was 18 minutes; control, 9 minutes; prothrombin time, 181/2 minutes; control, $7 \frac{1}{2}$ minutes.

February 6 , the patient received 15 c.c. of autogenous serum, without immediate reaction. The patient could not be reached after this visit.

CASE 6.-E. D., aged 29, maid, was admitted to the medical service of the Presbyterian Hospital, June 24, 1916, where she remained, with short leaves, until Oct. 2, 1916. She complained of hives and swelling of her face for the previous three months. Family history negative; no asthma, hay-fever or eczema. As a child, she had had measles, scarlet fever and diphtheria without antitoxin. Her tonsils were removed fifteen years previously. She had had a slight attack of rheumatism five years previously. Her appetite was good, bowels regular, urination normal and habits good. She had always been nervous. Three months prior to admission she had had a severe gastro-intestinal attack, with nausea, vomiting and diarrhea, lasting twelve hours. The next morning her eyes and lips were puffy and she had some hives. Since then until admission she had had recurrring swellings of her face, with severe urticaria, itching intolerably. She had "tried everything" without relief. Examination showed nothing abnormal except extensive urticaria and swollen eyelids and lips. The blood pressure was 126-80; urine, negative; hemoglobin, 90 per cent.; leukocytes, 7,000; polymorphs, 67 per cent.; lymphocytes, 33 per cent.; no eosinophils; weight, 111 pounds.

June 26, prothrombin time, 17 minutes; control, 8 minutes; coagulation time of whole blood, 14 minutes; control, 6 minutes. While in the hospital she had a curettage for a chrnnic leucorrhea. During this time she received four doses of heterogeneous human serum intravenously, each dose averaging 15 c.c. 
August 25, patient returned to the hospital, having had an acute gastrointestinal upset three days previously, and reporting that the hives and facial swellings were still as bad as ever. She was tried out with various dietetic restrictions, calcium lactate, epinephrin and atropin and colon irrigations-all without the slightest effect. Skin tests for sensitization to foreign proteins were always unsatisfactory, as the patient was continually having urticaria, which made the readings worthless. She received four doses of her own ser um, 20 c.c. at a time. September 9, her coagulation time (whole blood) was 121/2 minutes; control, 9 minutes; prothrombin time, 13 minutes; control. 10 minutes. The patient was seen in the dispensary at two-week intervals until December 1, and reported absolutely no improvement.

TABle 3.-Results on Blood with Heterogeneous and Autogenous Serum

\begin{tabular}{|c|c|c|c|c|c|c|c|c|c|c|c|c|}
\hline \multirow{3}{*}{ Patient } & \multirow{3}{*}{\multicolumn{2}{|c|}{ Date }} & \multirow{2}{*}{\multicolumn{2}{|c|}{$\begin{array}{c}\text { Coagu- } \\
\text { lation } \\
\text { Time } \\
\text { of Whole } \\
\text { Blood }\end{array}$}} & \multirow{2}{*}{\multicolumn{2}{|c|}{$\underset{\text { bin }}{\text { Prothrom. }}$}} & \multicolumn{6}{|c|}{ Antithrombin (Hess Method) } \\
\hline & & & & & & & \multicolumn{2}{|c|}{ Control } & \multicolumn{2}{|c|}{$\begin{array}{l}3 \text { Drops } \\
\text { Anti- } \\
\text { thrombin }\end{array}$} & \multicolumn{2}{|c|}{$\begin{array}{l}5 \text { Drops } \\
\text { Anti- } \\
\text { thrombin }\end{array}$} \\
\hline & & & Min. & Sec. & Min. ! & Sec. & Min. & Sec. & Min. & Sec. & Min. & Sec. \\
\hline \multirow[t]{3}{*}{ 3. L.M.S } & $4 / 19 / 16$ & $\begin{array}{l}\text { No treatment } \\
\text { with serum } \\
\text { Control......... }\end{array}$ & $\begin{array}{r}20 \\
8\end{array}$ & $\begin{array}{l}\cdots \\
\ldots\end{array}$ & $\begin{array}{r}17 \\
9\end{array}$ & $\begin{array}{l}\cdots \\
. .\end{array}$ & $\begin{array}{l}\tau \\
\cdots\end{array}$ & $\begin{array}{l}\cdots \\
. .\end{array}$ & $\begin{array}{l}6 \\
7\end{array}$ & $\begin{array}{l}30 \\
\ldots\end{array}$ & $\begin{array}{l}9 \\
7\end{array}$ & $\begin{array}{l}30 \\
30\end{array}$ \\
\hline & $5 / 29 / 16$ & $\begin{array}{l}2 \text { doses serum.... } \\
\text { Control.......... }\end{array}$ & $\begin{array}{l}18 \\
10\end{array}$ & .. & $\begin{array}{r}14 \\
7\end{array}$ & .. & $\begin{array}{c}8 \\
. \cdot\end{array}$ & $\begin{array}{l}30 \\
. \cdot\end{array}$ & $\begin{array}{r}9 \\
10\end{array}$ & 30 & $\begin{array}{l}14 \\
11\end{array}$ & $\begin{array}{l}30 \\
. .\end{array}$ \\
\hline & $9 / 12 / 16$ & $\begin{array}{c}\text { After } 6 \text { doses } \\
\text { serum } \\
\text { Control.......... }\end{array}$ & $\begin{array}{r}10 \\
8\end{array}$ & $\begin{array}{l}. . \\
. .\end{array}$ & $\begin{array}{l}9 \\
9\end{array}$ & $\begin{array}{l}. \\
30\end{array}$ & $\begin{array}{l}10 \\
\ldots\end{array}$ & $\begin{array}{l}30 \\
. .\end{array}$ & $\begin{array}{r}8 \\
10\end{array}$ & .. & $\begin{array}{l}10 \\
11\end{array}$ & $\begin{array}{l}\cdots \\
30\end{array}$ \\
\hline \multirow[t]{2}{*}{ 4. J.s. } & $4 / 14 / 16$ & $\begin{array}{l}\text { No treatment... } \\
\text { Control.......... }\end{array}$ & $\begin{array}{l}14 \\
10\end{array}$ & $\because$. & $\begin{array}{l}11 \\
11\end{array}$ & $\ddot{30}$ & $\begin{array}{l}10 \\
. .\end{array}$ & $\ddot{.}$ & $\begin{array}{l}12 \\
10\end{array}$ & $\therefore$ & $\begin{array}{l}11 \\
11\end{array}$ & $\begin{array}{l}30 \\
\cdots\end{array}$ \\
\hline & $10,14 / 16$ & $\begin{array}{c}\text { After } 6 \text { doses } \\
\text { serum } \\
\text { Control........ }\end{array}$ & $\begin{array}{l}9 \\
7\end{array}$ & $\begin{array}{l}30 \\
\ldots\end{array}$ & $\begin{array}{l}10 \\
10\end{array}$ & $\begin{array}{l}\cdots \\
30\end{array}$ & $\begin{array}{l}7 \\
.\end{array}$ & $\begin{array}{l}\cdots \\
.\end{array}$ & $\begin{array}{l}7 \\
7\end{array}$ & $\begin{array}{l}30 \\
. .\end{array}$ & $\begin{array}{l}8 \\
8\end{array}$ & $\begin{array}{l}30 \\
\ldots\end{array}$ \\
\hline 5. K. H. & $1 / 18 / 16$. & 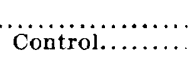 & $\stackrel{18}{y}$. & $\because$. & $\begin{array}{r}18 \\
\pi\end{array}$ & $\begin{array}{l}30 \\
30\end{array}$ & .. & .. & $\because$ &.. & $\because$. & $\because$ \\
\hline 6. E. I). & $6 / 26 / 16$ & 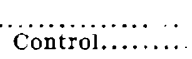 & $\begin{array}{r}14 \\
6\end{array}$ & $\because$. & $\begin{array}{r}17 \\
8\end{array}$ & $\because$ & $\because$. & $\begin{array}{l}. . \\
. .\end{array}$ & $\because$. & $\because$ & ... & $\because$ \\
\hline & 9/ $9 / 16$. & 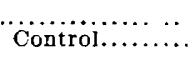 & $\begin{array}{r}12 \\
9\end{array}$ & $\begin{array}{l}30 \\
. .\end{array}$ & $\begin{array}{l}13 \\
10\end{array}$ & . & $\ddot{.}$ & $\because$. & 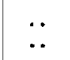 & $\because$. & $\ddot{.}$ & $\begin{array}{l}. . \\
. .\end{array}$ \\
\hline 7. J. 1. & $9 / 21 / 16$ & 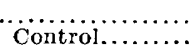 & $\begin{array}{l}14 \\
10\end{array}$ & .. & $\begin{array}{r}15 \\
9\end{array}$ & $\begin{array}{l}30 \\
. .\end{array}$ & $\begin{array}{c}9 \\
. .\end{array}$ &.. & $\begin{array}{l}8 \\
9\end{array}$ & $\begin{array}{l}30 \\
. \cdot\end{array}$ & $\begin{array}{r}9 \\
10\end{array}$ & 30 \\
\hline & $11 / 2 / 16$ & $\begin{array}{l}\text { After serum...... } \\
\text { Control............. }\end{array}$ & $\begin{array}{r}12 \\
9\end{array}$ &. & $\begin{array}{l}10 \\
10\end{array}$ & $\ddot{*}$ &. &.. &. & .. & $\because$. & $\because$. \\
\hline
\end{tabular}

Case 7.-Mrs. J. I., aged 30, teacher, was admitted to the Presbyterian Hospital, Sept. 1, 1916; discharged Sept. 30, 1916. Diagnosis, angioneurotic edema and urticaria. Her complaint was hives and facial swellings for six weeks. The family history was negative for urticaria, eczema, asthma and hay-fever. She had had the usual children's diseases, including diphtheria, without antitoxin. Two years prior to admission both ovaries were removed for cysts, and she had been troubled with hot flushes and headaches since then. She tired easily; appetite was good; bowels regular; urination normal. She had had no children; no miscarriages. Fifteen years prior to admission the patient had an attack of angioneurotic edema and urticaria like the present attack; it lasted for two years, and she had no further trouble until the present attack. For

20. Kahn and Emsheimer: The Archives Int. Med., 1916, 18, 445. 
one month the patient had had swellings of lips and eyes and severe general urticaria, not influenced by dieting or medication. During the previous two weeks the patient had noticed small black and blue spots over her thighs and legs. She was well nourished and quite nervous. The left eye was swollen almost shut and she had some urticarial wheels scattered over back and abdomen. There were a few purpuric spots scattered over her thighs and legs. Otherwise, the examination showed nothing abnormal. The hemoglobin was 86 per cent.; leukocytes, 6,600; polymorphs, 66 per cent.; lymphocytes, 34 per cent.; no eosinophils. Coagulation time of whole blood, 14 minutes; control, $91 / 2$ minutes; prothrombin time, $13 \frac{1}{1} 2$ minutes; control, 8 minutes. She was given a diet without fish, milk, eggs, meat or cheese, and calcium lactate. She rapidly improved, but thought that when lamb chops were later added she became worse. During her stay in the hospital she was given two doses of autogenous serum (20 c.c. each). Intracutaneous tests for sensitization showed positive reaction to phaseolin (beans), beef and pig. She was put on a diet that excluded these articles and discharged. Following her discharge she improved markedly, had no swellings of her face and "the hives had been much better." She had one severe attack after eating beef, but ate pork with impunity.

November 2, coagulation time of whole blood, 12 minutes; control, 9 minutes; prothrombin time, 10 minutes; control, 10 minutes.

Nothing was found to explain why the delayed coagulation time of the whole blood and the delayed prothrombin time disappeared with an approach to normal figures in three out of the four cases of urticaria treated with serum. If, as some ${ }^{20}$ think, by the introduction of autogenous defibrinated blood or blood serum an appropriate antigen is introduced to create the appropriate antibodies for the production of active immunization, then it is possible that the anaphylactic state is overcome, and hence the coagulation factors of the blood change to normal. But, as we are dealing with so complex and so little understood a substance as blood serum, no definite conclusion can be reached.

The author is not prepared to assert anything at this time as to the therapeutic value of human serum in clinical anaphylaxis in man. This problem is now being investigated, and the results will be reported at another time.

\section{SUMMARY}

1. Studies with anaphylactic guinea-pig's blood showed a delay in the coagulation time of the whole blood and in the prothrombin time. Determinations of antithrombin content were inconstant and unsatisfactory, but there seemed to be a tendency to higher figures in the case of the anaphylactic blood.

2. Studies with the blood of patients suffering from serum sickness showed a marked delay in the coagulation time of the whole blood, and of the prothrombin time during the serum sickness, with a later fall to nearly, but not entirely, normal figures for both after the disappearance of the serum sickness. The results with the antithrombin content were inconclusive. 
3. Studies of the blood of patients suffering with chronic urticaria showed a.delayed coagulation time and prothrombin time in four out of five cases, with an approach to normal figures after the patients had been treated intravenously with autogenous or heterogenous serum in three cases out of four.

The funds necessary to carry out the foregoing study were supplied by Mrs. Arthur W. Swann, in memory of the late Dr. Arthur W. Swann. I wish to thank Dr. W. G. McCallum, Dr. Warfield T. Longcope and Dr. Albert R. Lamb for their constant assistance and cooperation.

771 Madison Avenue. 